\title{
Kepemilikan Keluarga dan Kebijakan Dividen dengan Moderasi Kepemilikan Asing
}

\author{
Made Gitanadya Ayu Aryani* \\ Universitas Airlangga \\ Dendy Aryo Wicaksono \\ Universitas Airlangga \\ *made.gitanadya.ayu.a@feb.unair.ac.id
}

\begin{abstract}
Abstrak
Perusahaan keluarga memegang peranan penting dalam perekonomian Indonesia. Hasil survei PricewaterhouseCoopers di tahun 2014 menyatakan bahwa 95\% bisnis di Indonesia dimiliki oleh keluarga dan data Boston Consulting Group di tahun 2016 menunjukkan 40\% kapitalisasi saham di Bursa Efek Indonesia adalah dari perusahaan keluarga. Penelitian ini bertujuan untuk mengetahui pengaruh kepemilikan keluarga terhadap kebijakan dividen dengan dimoderasi oleh kepemilikan asing. Obyek dari penelitian ini adalah perusahaan keluarga yang ditandai adanya kepemilikan individu anggota keluarga tanpa batas minimal. Penelitian ini menggunakan model analisis regresi linear berganda dengan sampel 58 perusahaan non keuangan yang tercatat di Bursa Efek Indonesia pada periode 2013-2017. Hasil menunjukkan bahwa kepemilikan keluarga memiliki pengaruh negatif signifikan terhadap kebijakan dividen dan kepemilikan asing memperlemah pengaruh negatif signifikan kepemilikan keluarga terhadap kebijakan dividen.
\end{abstract}

Kata Kunci: kepemilikan keluarga, kebijakan dividen, kepemilikan asing, perusahaan keluarga

\section{Pendahuluan}

Terdapat empat jenis kepemilikan saham dalam suatu perusahaan yaitu kepemilikan individu, institusional, asing dan keluarga. Penelitian ini akan berfokus pada kepemilikan keluarga karena mendominasi jenis perusahaan di Indonesia. Hasil survei dari Pricewaterhouse Coopers pada tahun 2014 menunjukkan bahwa 95\% bisnis di Indonesia dimiliki atau dikelola oleh keluarga. Data dari Boston Consulting Group tahun 2016 juga menunjukkan bahwa kurang lebih $40 \%$ dari kapitalisasi pasar di pasar saham Indonesia adalah perusahaan keluarga. Kedua data ini menunjukkan besarnya pengaruh perusahaan keluarga dalam perekonomian Indonesia sehingga layak untuk diteliti lebih mendalam.

Keluarga dapat terlibat dalam pihak internal maupun eksternal perusahaan. Sebagai pihak eksternal perusahaan, keluarga dapat menjadi pihak pemegang saham mayoritas. Pemegang saham keluarga mempunyai andil besar dalam keputusan perusahaan dan mempunyai pengaruh yang besar melalui hak voting atau voting right, sedangkan sebagai pihak internal perusahaan, keluarga biasanya ikut duduk di dalam jajaran manajemen. 
De Angelo et al. (2009) menjelaskan bahwa preferensi pemegang saham pengendali memiliki pengaruh besar pada kebijakan dividen. Untuk menentukan jumlah dividen yang dibayarkan, banyak hal yang harus dipertimbangkan oleh manajemen. Manajemen harus memikirkan kesejahteraan para pemegang saham yang menuntut dividen tinggi, tetapi di sisi lain ada pertimbangan kebutuhan investasi demi keberlangsungan perusahaan.

Ada dua pandangan yang bertolak belakang mengenai pengaruh kepemilikan keluarga terhadap kebijakan dividen perusahaan. Pengembangan dari teori keagenan menyatakan bahwa semakin tinggi kepemilikan keluarga dapat mengurangi dividen yang akan dibayarkan oleh perusahaan. Hal tersebut karena kepemilikan saham keluarga dapat menimbulkan sebuah konflik yang berkaitan dengan masalah keagenan yang dimana pihak keluarga dapat menyalahgunakan kekuasaan yang dimilikinya demi keuntungan diri sendiri. (Reyna, 2015)

Tetapi, ada juga pendapat yang menyatakan kepemilikan keluarga dapat menaikkan jumlah dividen yang dibayarkan perusahaan. Hal ini sesuai dengan teori stewardship, yang memprediksi bahwa anggota keluarga sebagai pengendali bertindak lebih seperti pelayan di perusahaan (Davis et al., 1997). Sebagai pelayan, mereka lebih memikirkan kelangsungan bisnis dan mengembangkan hubungan yang lebih dekat dengan para pemangku kepentingan perusahaan lainnya (Miller et al., 2008).

Selain kepemilikan keluarga, kepemilikan asing juga memiliki pengaruh terhadap kebijakan dividen perusahaan. Pemegang saham asing mendorong pembayaran dividen yang lebih tinggi (Gedajlovic et al., 2005). Hal ini dikarenakan pemegang saham asing berharap mendapatkan imbal hasil yang tinggi melalui dividen dan pemegang saham asing akan lebih berpihak kepada pemegang saham minoritas karena mempunyai kepentingan yang sama. Pemegang saham asing melakukan pengawasan lebih ketat sehingga dapat meminimalisir penyelewengan yang dilakukan manajer perusahaan (Najjar dan Kilincarslan, 2015).

Kebaruan penelitian ini adalah dilakukan pada perusahaan dengan kepemilikan individu dari anggota keluarga yang ditandai pemegang saham dengan nama belakang atau marga yang sama tanpa batas minimal. Hal ini disebabkan kebanyakan penelitian sebelumnya memiliki syarat kepemilikan keluarga minimal sebesar $20 \%$ untuk dapat diklasifikasikan sebagai perusahaan keluarga. Tujuan pemilihan sampel ini adalah untuk fokus mengetahui pengaruh langsung kepemilikan anggota keluarga tanpa ada batas minimal dan mengeluarkan perusahaan dengan skema kepemilikan piramida ataupun shell company. Merujuk latar belakang tersebut, akan menarik untuk meneliti pengaruh kepemilikan keluarga yang dimoderasi dengan kepemilikan asing pada perusahaan go public sektor non keuangan di Bursa Efek Indonesia.

\section{Landasan Teori dan Pengembangan Hipotesis}

Kepemilikan keluarga adalah perusahaan yang dikendalikan oleh keluarga pendiri, dimana pendiri atau keturunannya secara terus menerus memegang posisi di manajemen puncak, dewan komisaris, maupun pemegang saham terbesar perusahaan (Anderson dan Reeb 2003). Pada awalnya, perusahaan keluarga adalah perusahaan yang tertutup dan mendanai kegiatan operasional perusahaannya dari modal sendiri dan hutang pada pihak luar, akan tetapi seiring dengan perkembangan pasar modal, perusahaan-perusahaan keluarga ini kemudian menjadi perusahaan terbuka yang dimana perusahaan akan dapat memperoleh lebih banyak dana yang dapat digunakan untuk mengembangkan perusahaannya.

Salah satu konsekuensi dari go public adalah perusahaan dituntut untuk membagikan dividen kepada pemegang sahamnya. Ross et al. (2003:606) menyatakan bahwa dividen 
merupakan suatu bentuk pembayaran yang dilakukan oleh perusahaan kepada para pemiliknya baik dalam bentuk tunai maupun saham. Menurut Bhattacharya (1979), pengumuman pembagian dividen merupakan sinyal dari perusahaan bahwa perusahaan mempunyai kinerja baik yang mampu menghasilkan laba dan bisa dibagikan kepada pemegang saham. Semakin tinggi pembayaran dividen, maka respon pasar akan positif sehingga semakin banyak investor yang menanamkan modalnya di perusahaan, akan tetapi perusahaan mempunyai penawaran yang terbatas atas saham tersebut, maka hal ini membuat harga saham di suatu perusahaan tersebut akan naik. Sebaliknya juga, semakin rendah pembayaran dividen, maka respon pasar akan negatif karena investor membaca sinyal bahwa perusahaan akan mendapatkan laba yang rendah dimasa depan.

Faccio et al. (2001) menyebutkan bahwa kebijakan dividen dapat dimanfaatkan untuk melakukan ekspropriasi terhadap pemegang saham minoritas. Hal ini dilakukan dengan cara keluarga menuntut perusahaan untuk membayarkan dividen yang tinggi, sehingga secara tidak langsung perusahaan mentransfer arus kas ke keluarga. Ketika perusahaan membayarkan dividen yang tinggi, pemegang saham minoritas merasa mendapatkan keuntungan dari pembayaran dividen yang diterimanya, padahal dalam jangka panjang hal ini dapat merugikan perusahaan karena perusahaan dapat kehilangan kesempatan investasi yang dapat digunakan untuk mengembangkan perusahaan.

Teori stewardship juga menyebutkan pengaruh positif kepemilikan keluarga terhadap kebijakan dividen. Teori ini memprediksi bahwa anggota keluarga sebagai pengendali bertindak lebih seperti pelayan di perusahaan (Davis et al., 1997). Sebagai pelayan, mereka lebih memikirkan kelangsungan bisnis dan mengembangkan hubungan yang lebih dekat dengan para pemangku kepentingan perusahaan lainnya (Miller et al., 2008). Keluarga akan lebih mementingkan kelangsungan perusahaannya, oleh karena itu perusahaan akan membuat hubungan yang lebih baik dengan para pemegang saham lainnya. Keluarga juga akan memikirkan apa yang pemegang saham lainnya inginkan, salah satunya dengan cara pembayaran dividen.

Selain pihak keluarga, saham sebuah perusahaan juga dapat dimiliki oleh warga atau institusi asing. Undang-undang No. 25 Tahun 2007 pada pasal 1 angka 6 menyebutkan bahwa kepemilikan asing adalah kepemilikan saham oleh warga negara asing, badan usaha asing, dan pemerintah asing yang melakukan penanaman modal di wilayah Republik Indonesia. Investor asing yang menanamkan modalnya di Indonesia biasanya merupakan investor institusional asing yang dimana mempunyai modal besar, akses pasar modal dunia yang lebih luas, serta memiliki kemampuan yang baik dalam mengelola informasi dan analis fundamental yang baik sehingga ketika kepemilikan investor asing semakin besar, hal ini dapat mempengaruhi kebijakan perusahaan.

Salah satu kebijakan perusahaan yang dapat dipengaruhi investor asing adalah kebijakan dividen. Investor asing akan mengharapkan imbal hasil yang tinggi dari hasil investasinya, yaitu salah satunya dengan membagikan dividen yang tinggi. Hal ini juga sesuai dengan penelitian yang dilakukan oleh La Porta et al. (2000) yang berpendapat bahwa perusahaan yang dikendalikan oleh pemegang saham asing mempunyai mekanisme tata kelola perusahaan yang baik dan mewajibkan untuk membayar dividen dalam jumlah yang lebih besar. Dengan demikian, semakin tinggi kepemilikan asing dalam suatu perusahaan, maka dividen yang dibagikan juga semakin besar.

Penelitian sebelumnya pernah dilakukan oleh Sakawa dan Watanabel (2018) yang menguji pengaruh family control terhadap kebijakan dividen yang dimoderasi oleh 
kepemilikan asing pada 14.4991 perusahaan yang tercatat pada Tokyo Stock Exchange (TSE) di Jepang pada periode 2007 sampai 2016. Hasil dari penelitian ini menunjukkan bahwa family control berpengaruh positif terhadap kebijakan dividen, dan kepemilikan asing memoderasi pengaruh antara kepemilikan keluarga terhadap kebijakan dividen.

Penelitian lainnya pernah dilakukan oleh Benjamin et al., (2016) yang menguji pengaruh kepemilikan keluarga terhadap kebijakan dividen yang dilakukan pada perusahaan terdaftar di Bursa Malaysia pada periode 2005-2010. Hasil penelitian ini menunjukkan bahwa semakin tinggi kepemilikan keluarga, maka tingkat dividen yang dibayarkan juga semakin meningkat.

Reyna (2015) melakukan penelitian pada 88 perusahaan non keuangan yang terdaftar pada Bursa Efek Meksiko pada periode 2005-2013. Penelitian ini juga meneliti pengaruh kepemilikan keluarga terhadap kebijakan dividen. Hasilnya menunjukkan bahwa kepemilikan keluarga mempunyai pengaruh negatif terhadap kebijakan dividen, yaitu semakin besar jumlah kepemilikan keluarga, maka dividen yang dibayarkan semakin rendah.

Sakawa et al. (2018) berpendapat bahwa keluarga tidak ingin menjual saham yang dimilikinya, karena ketika keluarga menjual sahamnya, maka hak kontrolnya akan menurun. Hal ini juga sesuai dengan pendapat Isakov dan Weisskopf (2015) dalam Setianto dan Sari (2017) tentang income needs hypothesis yang menyatakan bahwa keluarga ingin memiliki kendali perusahaan dalam jangka panjang. Maka dari itu keluarga akan menuntut pembayaran dividen yang tinggi agar bisa menikmati modal yang telah ditanamkannya.

Teori stewardship juga mendukung pengaruh positif kepemilikan keluarga terhadap kebijakan dividen, yang dimana keluarga akan bertindak lebih sesuai seperti pelayan perusahaan yang memikirkan kepentingan pemegang saham, yang dimana pemegang saham menginginkan pembayaran dividen yang tinggi. Income needs hypothesis juga menjelaskan bahwa keluarga akan lebih menginginkan pembayaran dividen yang tinggi, karena keluarga akan kehilangan kendalinya jika menjual sahamya. Dari uraian diatas, maka dapat dirumuskan hipotesis pertama penelitian ini sebagai berikut :

\section{H1 : Kepemilikan keluarga berpengaruh positif terhadap kebijakan dividen}

Ketika tingkat kepemilikan keluarga di suatu perusahaan tinggi, keluarga sebagai pengendali tidak ingin menjual sahamnya dikarenakan keluarga ingin memiliki kendali dalam jangka panjang terhadap perusahaan. Hal ini menyebabkan pihak keluarga akan menuntut pembayaran dividen yang tinggi terhadap perusahaan. Investor asing mempunyai analisis fundamental yang baik dalam memilih perusahaan yang memberi imbal hasil yang tinggi, sehingga investor akan lebih menyukai perusahaan yang memiliki kepemilikan keluarga yang tinggi dikarenakan perusahaan dengan tingkat keluarga yang tinggi membayar dividen yang tinggi pula. Sehingga ketika kepemilikan asing di suatu perusahaan keluarga tinggi, hal ini akan memperkuat pengaruh kepemilikan keluarga yang menuntut pembayaran dividen lebih besar dari perusahaan. Dari uraian diatas, maka dapat dirumuskan hipotesis kedua sebagai berikut :

H2 : Kepemilikan asing memperkuat pengaruh positif kepemilikan keluarga terhadap kebijakan dividen.

Selain kepemilikan keluarga dan asing, penelitian ini juga menggunakan beberapa variabel kontrol yang dapat mempengaruhi kebijakan dividen perusahaan. Variabel kontrol pertama yang digunakan adalah leverage. Menurut Sudana (2015:23), leverage merupakan pemakaian utang oleh perusahaan yang digunakan untuk melakukan kegiatan operasional 
perusahaan atau dalam melakukan kegiatan investasi. Semakin tinggi leverage maka resiko keuangan perusahaan juga semakin tinggi karena semakin besar pula tingkat ketergantungan perusahaan terhadap pihak kreditur dan semakin besar pula beban biaya hutang (biaya bunga) yang harus dibayarkan oleh perusahaan, sehingga pendapatan yang didapat oleh perusahaan akan digunakan untuk membayar beban bunga tersebut. Hal ini akan menyebabkan laba yang diterima perusahaan akan berkurang sehingga dividen yang diterima pemegang saham juga semakin menurun. Hal ini sesuai dengan penelitian Chang dan Rhee (1990) yang menunjukkan bahwa tingkat hutang yang lebih tinggi menyebabkan pembayaran dividen perusahaan yang lebih rendah, sehingga leverage berpengaruh negatif terhadap dividen.

Variabel kontrol kedua adalah ukuran perusahaan. Menurut Brigham \& Houston (2010:4) ukuran perusahaan adalah besar kecilnya sebuah perusahaan yang dapat ditunjukkan dengan total aset, total penjualan, jumlah laba, beban pajak dan lain-lain. Ukuran perusahaan bisa digunakan sebagai sebuah pertimbangan untuk menentukan sejauh mana perusahaan mampu bertahan dengan keadaan finansial yang dimiliki sehingga semakin besar ukuran perusahaan, modal yang harus dimiliki juga semakin besar.

Ketika ukuran perusahaan semakin besar, maka perusahaan tersebut akan mempunyai akses yang lebih mudah terhadap pasar modal, sedangkan perusahaan yang masih kecil atau baru akan kesulitan untuk mendapatkan akses terhadap pasar modal. Dengan mudahnya akses terhadap pasar modal, maka perusahaan akan mempunyai banyak modal yang dapat digunakan perusahaan untuk mengelola perusahaannya untuk mendapatkan keuntungan yang selanjutnya dapat dibagikan kepada para pemegang saham dalam bentuk dividen. Penelitian yang dilakukan oleh Jensen et al. (1992), Reyna (2015), Fama dan French (2001) menunjukkan bahwa variabel ukuran perusahaan berpengaruh positif signifikan terhadap kebijakan dividen

Variabel kontrol terakhir dalam penelitian ini adalah profitablitas perusahaan. Profitabilitas biasanya diketahui dalam bentuk rasio yang mengukur kemampuan perusahaan dalam menghasilkan laba dengan menggunakan sumber-sumber yang dimiliki perusahaan, seperti aktiva, modal, atau penjualan perusahaan (Sudana, 2015). Perusahaan yang mendapatkan keuntungan lebih besar cenderung akan membayar porsi keuntungan yang lebih besar sebagai dividen. Chen dan Steiner (1999) berpendapat semakin tinggi laba, cash flow dalam perusahaan juga akan semakin tinggi, dengan hal ini diharapkan perusahaan membayarkan dividen yang tinggi. Penelitian yang pernah dilakukan oleh DeAngelo et al. (1992), Fama dan French (2001) menyatakan bahwa profitabilitas berpengaruh positif signifikan terhadap kebijakan dividen.

\section{Metode Penelitian}

Penelitian ini menggunakan pendekatan kuantitatif dengan tujuan untuk menganalisis pengaruh kepemilikan keluarga terhadap kebijakan dividen dengan kepemilikan asing sebagai variabel moderasi. Penelitian ini menggunakan data sekunder yang diperoleh dari laporan keuangan perusahaan non keuangan yang terdaftar pada Bursa Efek Indonesia (BEI) periode 2013-2017. Sampel penelitian ditentukan menggunakan metode purposive sampling dengan kriteria perusahaan non keuangan dengan kepemilikan keluarga yang bercirikan nama belakang / marga pemegang saham yang sama. Penelitian ini melakukan pengujian hipotesis dengan menggunakan analisis regresi linier berganda.

Variabel dependen dalam penelitian ini adalah kebijakan dividen perusahaan yang diukur dengan Dividend Payout Ratio (DPR). Variable independen dalam penelitian ini menggunakan kepemilikan keluarga. Variabel moderasi dalam penelitian ini adalah 
kepemilikan asing. Penelitian ini juga menggunakan tiga variabel kontrol yaitu leverage yang diukut dengan Debt to Total Assets Ratio, ukuran perusahaan yang diukur dengan logaritma natural dari aset total perusahaan serta profitabilitas yang diukur dengan Return to Assets Ratio.

Berikut adalah model penelitian yang digunakan

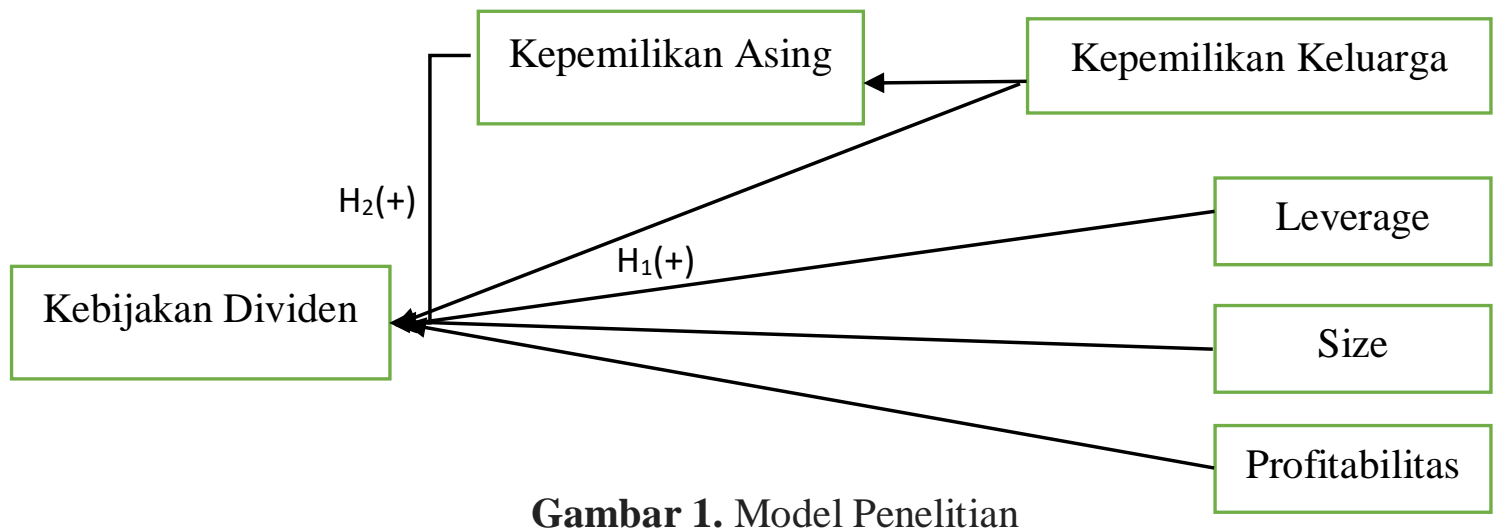

Model analisis dalam penelitian ini adalah regresi linier berganda. Model persamaan yang digunakan untuk menguji hipotesis adalah :

$$
D P R_{\mathrm{i}, \mathrm{t}}=\beta_{0}+\beta_{1} F A M_{\mathrm{i}, \mathrm{t}}+\beta_{2} F A M * F O R_{\mathrm{i}, \mathrm{t}}+\beta_{3} L E V_{\mathrm{i}, \mathrm{t}}+\beta_{4} S I Z E_{\mathrm{i}, \mathrm{t}}+\beta_{5} R O A_{\mathrm{i}, \mathrm{t}}
$$

Keterangan:

$\beta_{0}$

$\beta_{1,2,3,4,5}$,

$=$ konstanta

$\mathrm{DPR}_{\mathrm{i}, \mathrm{t}}$

$=$ koefisien regresi

$\mathrm{FAM}_{\mathrm{i}, \mathrm{t}}$

$=$ kebijakan dividen perusahaan i pada tahun $\mathrm{t}$

$\mathrm{FOR}_{\mathrm{i}, \mathrm{t}}$

$=$ kepemilikan keluarga perusahaan i pada tahun $\mathrm{t}$

$\mathrm{LEV}_{\mathrm{i}, \mathrm{t}}$

$=$ kepemilikan asing perusahaan i pada tahun $\mathrm{t}$

$\mathrm{SIZE}_{\mathrm{i}, \mathrm{t}}$

$=$ leverage perusahaan i pada tahun $\mathrm{t}$

$\mathrm{ROA}_{\mathrm{i}, \mathrm{t}}$

$=$ ukuran perusahaan i pada tahun $\mathrm{t}$

$=$ proftabilitas perusahaan $\mathrm{i}$ pada tahun $\mathrm{t}$

Tabel 1. Definisi Operasional dan Pengukuran Variabel

\begin{tabular}{|l|l|}
\hline \multicolumn{1}{|c|}{ Variabel } & \multicolumn{1}{c|}{ Pengukuran } \\
\hline $\begin{array}{l}\text { Kebijakan Dividen } \\
\text { (DPR) }\end{array}$ & $\begin{array}{l}\text { Persentase besarnya dividen yang dibagikan kepada pemegang saham } \\
\text { dalam bentuk tunai dibandingkan laba bersih perusahaan }\end{array}$ \\
\hline $\begin{array}{l}\text { Kepemilikan } \\
\text { Keluarga (FAM) }\end{array}$ & $\begin{array}{l}\text { Persentase kepemilikan saham perusahaan yang dimiliki oleh keluarga } \\
\text { dibanding seluruh saham yang beredar }\end{array}$ \\
\hline $\begin{array}{l}\text { Kepemilikan Asing } \\
\text { (FOR) }\end{array}$ & $\begin{array}{l}\text { Persentase kepemilikan saham perusahaan yang dimiliki oleh pihak asing } \\
\text { dibanding seluruh saham yang beredar }\end{array}$ \\
\hline Leverage (LEV) & Persentase jumlah hutang dibagi total asset perusahaan \\
\hline $\begin{array}{l}\text { Ukuran Perusahaan } \\
\text { (SIZE) }\end{array}$ & Logaritma natural dari total asset perusahaan \\
\hline Profitabilitas (ROA) & Persentase laba bersih dibanding total asset perusahaan \\
\hline
\end{tabular}


Berdasarkan kriteria penentuan sampel serta pengukuran variabel di atas, maka diperoleh data statistik deskriptif penelitian ini sebagai berikut:

Tabel 2. Statistik Deskriptif Variabel Penelitian

\begin{tabular}{|c|c|r|r|r|r|}
\hline Variabel & \multicolumn{1}{c|}{$\mathbf{N}$} & \multicolumn{1}{c|}{ Minimum } & \multicolumn{1}{c|}{ Maximum } & \multicolumn{1}{c|}{ Mean } & \multicolumn{1}{c|}{ Std. Deviation } \\
\hline$D P R$ & 276 & .0000000 & .9942519 & .116537968 & .1843608279 \\
\hline$F A M$ & 276 & .0000058 & .8731549 & .098746727 & .1815192479 \\
\hline$F O R$ & 276 & .0000000 & .8731500 & .171062319 & .2213945328 \\
\hline$L E V$ & 276 & .0734679 & 1.9227839 & .507608058 & .2505466212 \\
\hline$S I Z E$ & 276 & 24.8992414 & 32.1509768 & 28.129441572 & 1.5969030645 \\
\hline$R O A$ & 276 & -1.0721900 & .2077900 & .022741703 & .1052954257 \\
\hline
\end{tabular}

\section{Pembahasan}

Langkah pertama dalam melakukan analisa data adalah uji asumsi klasik. Uji asumsi klasik digunakan untuk menguji layak atau tidaknya model regresi untuk mendapatkan suatu hasil pengujian yang terbebas dari bias. Uji asumsi klasik terdiri dari uji normalitas, uji autokorelasi, uji moltikolinearitas, dan uji heteroskedastisitas dengan hasil sebagai berikut:

1. Uji Normalitas

Berdasarkan lampiran 4 yang menampilkan hasil uji normalitas dengan dengan uji statistik non-parametrik Kolmogorov-Smirnov, menunjukkan nilai signifikansi (2tailed) sebesar 0,202 maka dari itu model regresi dalam penelitian ini memenuhi uji normalitas.

2. Uji Multikolinearitas

Berdasarkan lampiran 4 yang menampilkan hasil uji multikolinearitas, variabel kepemilikan keluarga (FAM), kepemilikan asing (FOR), FAM*FOR, leverage (LEV), ukuran perusahaan (SIZE), return on assetss (ROA) memiliki nilai tolerance value > 0,10 dan nilai VIF < 10, maka tidak terjadi multikolinearitas atau lolos uji multikolinearitas..

3. Uji Autokorelasi

Berdasarkan lampiran 4 yang menampilkan hasil output SPSS, nilai DW pada model sebesar 1,328 sehingga tidak mengalami autokorelasi karena nilai DW diantara -2 dan $2(-2<\mathrm{DW}<2)$

4. Uji Heteroskedastisitas

Berdasarkan lampiran 4 yang menampilkan hasil uji heteroskedastisitas berupa grafik scatterplot menunjukkan tidak membentuk sebuah pola tertentu atau tersebar secara acak, maka dari itu dapat disimpulkan bahwa tidak terjadi heteroskedastisitas.

Setelah lolos uji asumsi klasik maka dilakukan analisis regresi berganda dengan bantuan software SPSS dengan hasil sebagai berikut: 
INOBIS: Jurnal Inovasi Bisnis dan Manajemen Indonesia Volume 02, Nomor 04, September 2019

Made Gitanadya Ayu Aryani, Dendy Aryo Wicaksono

Tabel 3. Hasil Analisis Regresi

\begin{tabular}{|c|c|c|}
\hline Variabel Independen & Koefisien & Signifikansi \\
\hline Konstanta & $-0,754$ & $0,000 * * *$ \\
\hline$F A M$ & $-0,126$ & $0,045 * *$ \\
\hline FOR & 0,14 & 0,786 \\
\hline$F A M * F O R$ & 0,990 & $0,086^{*}$ \\
\hline$L E V$ & $-0,156$ & $0,002 * *$ \\
\hline SIZE & 0,34 & $0,000 * * *$ \\
\hline ROA & 0,206 & $0,087 *$ \\
\hline $\mathrm{R}^{2}$ & 0,187 & \\
\hline
\end{tabular}

Hasil dari pengujian hipotesis 1 adalah ditolak yang menunjukkan bahwa kepemilikan keluarga berpengaruh negatif signifikan terhadap kebijakan dividen. Hal ini disebabkan karena semakin tinggi kepemilikan keluarga di sebuah perusahaan, dapat menimbulkan sebuah konflik yang berhubungan dengan masalah keagenan, yaitu pihak keluarga akan melakukan ekspropriasi terhadap pemegang saham minoritas dengan menggunakan laba yang dimiliki perusahaan untuk kepentingan pihak keluarga (Shabbir et al., 2013) dalam (Reyna, 2015), sehingga porsi laba perusahaan yang digunakan untuk membayarkan dividen akan semakin kecil. Di sisi lain, Jensen et al., (1976) berpendapat bahwa pada tingkat kepemilikan tinggi, motif ekspropriasi oleh pemegang saham pengendali bisa lebih rendah. Hal ini disebabkan karena keluarga lebih mementingkan keberlangsungan perusahaan dalam jangka panjang. Maka perusahaan akan memilih menggunakan laba yang dimilikinya untuk mengembangkan perusahaan dibandingkan untuk dibayarkan sebagai dividen.

Sakawa et al. (2018) berpendapat bahwa keluarga tidak ingin menjual saham yang dimilikinya, karena ingin memiliki kendali yang besar terhadap perusahaan, karenanya ketika kontrol keluarga di suatu perusahaan tinggi, perusahaan membayarkan dividen yang lebih rendah, hal ini dikarenakan pembayaran dividen yang tinggi dapat menjadi sinyal positif bagi pasar, sehingga ketika semakin banyak pemegang saham di suatu perusahaan, maka dapat menurunkan hak kontrol keluarga terhadap perusahaan. Maka dari itu, semakin tinggi kepemilikan keluarga, dividen yang dibayarkan akan semakin menurun. Hal ini sesuai dengan penelitian Reyna (2015).

Kepemilikan asing dalam penelitian ini jika sebagai variabel moderasi memiliki hasil yang signifikan, tetapi sebagai variabel independen tidak signifikan. Hal ini menunjukkan bahwa variabel kepemilikan asing merupakan variabel moderasi murni (pure moderator). Hasil penelitian juga menolak hipotesis 2 , yaitu kepemilikan asing memperlemah pengaruh negatif kepemilikan keluarga terhadap kebijakan dividen. Semakin tinggi kepemilikan asing di suatu perusahaan akan mengurangi motif ekspropriasi pihak keluarga terhadap perusahaan, hal ini dikarenakan pemegang saham asing melakukan pengawasan lebih ketat, sehingga penyalahgunaan laba yang dilakukan terhadap perusahaan akan berkurang, sehingga porsi dividen yang dibagikan perusahaan akan bertambah.

Hasil ini sesuai dengan penelitian Gedajlovic et al. (2005) bahwa pemegang saham asing mendorong pembayaran dividen yang lebih tinggi. Hal ini dikarenakan investor asing 
mempunyai banyak kelebihan, diantaranya mempunyai modal yang besar, akses pasar modal dunia yang lebih luas, analis fundamental yang baik dan memiliki kelebihan dalam mengelola informasi. Sehingga pemegang saham asing akan menuntut imbal hasil yang tinggi melalui dividen dan pemegang saham asing akan lebih berpihak kepada pemegang saham minoritas karena mempunyai kepentingan yang sama. Maka dari itu, semakin tinggi kepemilikan asing, maka akan memperlemah pengaruh negatif kepemilikan keluarga terhadap kebijakan dividen.

Untuk variabel kontrol yang pertama, hasil regresi menunjukkan bahwa leverage berpengaruh negatif signifikan terhadap kebijakan dividen. Hal ini menunjukkan ketika tingkat leverage di suatu perusahaan meningkat maka dividend payout ratio akan menurun. Semakin besar proporsi penggunaan utang yang digunakan untuk membiayai investasi pada aktiva juga akan menyebabkan beban bunga yang harus dibayarkan perusahaan semakin besar sehingga mengurangi pendapatan yang diperoleh perusahaan dan dividen yang diterima pemegang saham juga semakin menurun. Hal ini sesuai dengan penelitian Chang dan Rhee (1990) yang menunjukkan bahwa tingkat hutang yang lebih tinggi menyebabkan pembayaran dividen perusahaan yang lebih rendah.

Hasil variabel kontrol yang kedua adalah ukuran perusahaan berpengaruh positif signifikan terhadap kebijakan dividen, maka semakin besar ukuran perusahaan, dividend payout ratio juga semakin besar. Perusahaan yang mempunyai ukuran besar akan lebih mudah dalam mengakses pasar modal. Dengan mudahnya akses terhadap pasar modal, maka perusahaan akan mempunyai banyak modal yang dapat digunakan perusahaan untuk mengelola perusahaannya untuk mendapatkan keuntungan yang selanjutnya dapat dibagikan kepada para pemegang saham dalam bentuk dividen. Penelitian yang dilakukan oleh Jensen et al. (1992), Reyna (2015), Fama dan French (2001) menunjukkan bahwa variabel ukuran perusahaan berpengaruh positif signifikan terhadap kebijakan dividen.

Variabel yang terakhir yaitu profitabilitas memiliki pengaruh positif signifikan terhadap kebijakan dividen, maka semakin tinggi rasio return on assetss, kemampuan perusahaan dalam mengoperasikan keseluruhan aktiva yang dimilikinya juga semakin baik, selain itu perusahaan yang mendapatkan keuntungan lebih besar cenderung akan membayar porsi keuntungan yang lebih besar sebagai dividen. Hasil ini sesuai dengan penelitian yang pernah dilakukan oleh DeAngelo et al. (1992), Fama dan French (2001) menyatakan bahwa return on assetss berpengaruh positif signifikan terhadap kebijakan dividen.

\section{Kesimpulan}

Penelitian ini bertujuan untuk mengetahui pengaruh kepemilikan keluarga terhadap kebijakan dividen yang dimoderasi kepemilikan asing pada perusahaan keluarga sektor non keuangan yang terdaftar di Bursa Efek Indonesia periode 2013 - 2017. Kebaruan penelitian ini adalah secara spesifik melihat kepemilikan perorangan dalam keluarga tanpa ada batas minimal. Hasil penelitian menunjukkan bahwa kepemilikan keluarga berpengaruh negatif signifikan terhadap kebijakan dividen. Hal ini menunjukkan ketika kepemilikan keluarga di suatu perusahaan tinggi, maka dividen yang dibayarkan oleh perusahaan akan semakin rendah. Kepemilikan asing akan memperlemah pengaruh negatif kepemilikan keluarga terhadap kebijakan dividen. Hal ini menunjukkan ketika kepemilikan asing di suatu perusahaan tinggi maka akan menaikkan dividend payout ratio suatu perusahaan.

Saran bagi penelitian berikutnya adalah memperluas sampel penelitian karena system kepemilikan di Indonesia banyak menggunakan sistem piramida sehingga pihak keluarga tidak terlibat langsung dalam kepemilikan perusahaan melainkan melalui perusahaan cangkang / 
shell company. Peneliti selanjutnya juga dapat menambahkan variabel lainnya untuk menjelaskan kebijakan dividen pada perusahaan keluarga.

\section{Daftar Pustaka}

Al-Najjar, B. dan Kilincarslan, E. (2016). "The Effect of Ownership Structure on Dividend Policy: Evidence from Turkey". Corporate Governance, 16(1), 135-161.

Anderson, R. C. dan D. M. Reeb. (2003). "Founding-Family Ownership and Firm Performance: Evidence from the S\&P 500". Journal of Finance, 58 (3), 1301-1328.

Andres, Christian. (2008). "Large shareholders and firm performance - An empirical examination of founding-family ownership". Journal of Corporate Finance, 14, 431445.

Aryani, M.G.A., Soeharto, S.M. dan Ariyani, I.. (2020). "Family Ownership and Control in Dividend And Leverage Decision Making”. Advances in Business, Management and Entrepreneurship, pp.366-370.

Benjamin, S. J., Wasiuzzaman, S., Mokhtarinia, H., dan Rezaie Nejad, N. (2016). "Family Ownership And Dividend Payout In Malaysia". International Journal of Managerial Finance, 12(3), 314-334.

Bhattacharya,S. (1979). "Imperfect Information, Dividend Policy and The Bird in The Hand Fallacy". Journal of Economics, 10, 259-27.

Brigham, E.F. dan J.F. Houston. (2010). Dasar - Dasar Manajemen Keuangan. Edisi 11. Jakarta: Salemba Empat.

Chang dan Rhee. (1990). "Empirical Analysis of Cash Dividend Payment in Chinese Listed Companie". Nature and Science, 21-31.

Chen, C. R., dan Steiner T. L. (1999). "Managerial Ownership and Agency Conflict: A Nonlinear Simultaneous Equation Analysis of Managerial Ownership, Risk Taking, Debt Policy, and Dividend Policy". Financial Review, 34, 119-137.

Davis, J.H., Schoorman, F.D. dan Donaldson, L. (1997). "Toward A Stewardship Theory Of Management". Academy of Management Review, 22(1), 20-47.

DeAngelo, H., DeAngelo, L., dan Douglas. (1992). "Dividends and Lossess". The Journal of Finance, 47(5), 1837-1863.

DeAngelo, H., DeAngelo, L, dan Skinner, D. (2009). "Corporate Payout Policy”. Foundations and Trends in Finance, 3(2), 95-287.

Fama, EF., dan French, K.R. 2001. "Disappearing Dividends: Changing Firm Characteristic or Lower Propensity to Pay". Journal of Financial Economic, 61: 3-43.

Faccio, M., Lang, L.H.P., dan Young, L. (2001). "Dividends and Expropriation". American Economic Review. 91(1): 55-79.

Gedajlovic, E., Yoshikawa, T. dan Hashimoto, M. (2005). “Ownership Structure, Investment Behavior And Firm Performance In Japanese Manufacturing Industries". Organization Studies, 26(1), 7-35.

Isakov, Dusan, dan Weisskopf. (2015). "Pay-Out Policies In Founding Family Firms". Journal of Corporate Finance, 33, 330-344.

Jensen, G. R., Solberg, D.P. dan Zorn T.S. (1992). "Simultaneous Determination of Insider Ownership, Debt and Dividend Policies". Journal of Financial and Quantitative Analysis, 247-263.

Jensen, M. (1986). "Agency Costs of Free Cash Flow, Corporate Finance, and Takeovers". American Economic Review, 76, 323-329. 
Jensen, MC., dan Meckling, WH. 1976. "Theory of the Firm: Managerial Behavior, Agency Costs and Ownership Structure". Journal of Financial Economics, 3(4), 305-360.

Johnson, S., La Porta, R., Lopez-De-Silanes, F., dan Sheleifer, A. (2000). "Tunneling". American Economics Review, 90: 22-27.

La Porta, R., Lopez-de-Silanes, F., dan Shleifer, A. (1999). “Corporate Ownership Around The World”. The Journal f oFinance, 54(2), 471-517.

Madyan, M., Meidiaswati, Sasikirono dan Herlambang. (2019). "Family Control, Institutional Ownership, Dan Kebijakan Dividen Perusahaan Manufaktur Yang Terdaftar Di Bursa Efek Indonesia”. Jurnal Reviu Akuntansi dan Keuangan, 9(1), 87-95.

Miller, D., Le Breton-Miller, I. dan Scholnick, B. (2008), "Stewardship Vs. Stagnation: An Empirical Comparison Of Small Family And Non-Family Businesses", Journal of Management Studies, 45(1), 51-78.

Najjar,Basil Al., dan Kilincarlsan, E., (2016). "The Effect Of Ownership Structure On Dividend Policy: Evidence From Turkey". Journal Corporate Governance, Vol. 16 Iss 1 pp. $135-161$

Republik Indonesia. Keputusan Menteri Keuangan nomor 1055,KMK.013/1989 tentang Pembelian Saham oleh Pemodal Asing.

Republik Indonesia. Undang-undang Nomor 25 Tahun 2007 tentang Penanaman Modal.

Ross, SA., Westerfield, W., dan Jordan, B.W. 2003. "Fundamentals of Corporate Finance, International Edition". Sixth Edition. Singapore: Mc Graw-Hill.

Sakawa, H., dan Watanabel, N. (2019). Family Control And Ownership Monitoring In Stakeholder-Oriented Corporate Governance. Management Decision, 57(7), 17121728.

Setianto, R. H., dan Sari, P. K. (2017). "Perusahaan Keluarga dan Kebijakan Dividen di Indonesia". Jurnal Siasat Bisnis, 21(2), 107-118.

Shabbir, A., Safdar, H., dan Aziz, B. (2013). "Corporate Governance Through Ownership Structure: Evidence From KSE-100 Index". South Asian Journal of Management Sciences, 7(2), 68-81.

Sudana, I Made. (2015). Manajemen Keuangan Perusahaan: Teori dan Praktik. Edisi kedua. Jakarta:Erlangga. 